\author{
${ }^{1} \mathrm{~S}$. Abbaszadeh, ${ }^{2} \mathrm{M}$. Nikbakht, ${ }^{3 *}$ P. Ramezannezhad, \\ ${ }^{4}$ M. Sagharjoghi Farahani, ${ }^{5}$ S.A.Y. Ahmadi, ${ }^{1}$ A. Safarzadeh
}

\author{
${ }^{1}$ Department of Clinical Biochemistry, Lorestan University of Medical Sciences, Khorramabad, Iran \\ ${ }^{2}$ Department of Medical Nanotechnology, Tehran University of Medical Sciences, Tehran, Iran \\ ${ }^{3}$ Cellular and Molecular Research Center, Shahrekord University of Medical Sciences, Shahrekord, Iran \\ ${ }^{4}$ Islamshahr Branch, Islamic Azad University, Islamshahr, Iran \\ ${ }^{5}$ Pediatric Growth and Development Research Center, \\ Institute of Endocrinology and Metabolism; University of Medical Sciences, Tehran, Iran \\ *e-mail: ramezannezhad.p@gmail.com
}

\title{
Some issues of nanometals applications in cancer treatment
}

\begin{abstract}
Nanotechnology and the use of innovative materials, such as nanoparticles, have created a new and effective approach to fight cancer. Several achievements in cancer therapy using metal nanoparticles and challenges facing them are presented in the current review. Cancer therapy requires teamwork with a multidisciplinary approach. It has different levels according to the type of cancer, including chemotherapy (induction, neoadjuvant, adjuvant, consolidation or maintenance chemotherapy), radiotherapy and surgical resection. Nanometals and nanodrugs may be used on the different levels of cancer therapy, especially in chemotherapy. Platinum $(\mathrm{Pt})$-based drugs are one group of the most effective drugs used for cancer chemotherapy. Gold nanoparticles are the other group of nanometals commonly used in cancer treatment. Although effectiveness of nanometals including gold-, silver-, and iron-based, has been investigated on different cancer cell lines and animal models both in vitro and in vivo, their effectiveness should also be explored from the viewpoints of evidence-based medicine.
\end{abstract}

Key words: cancer, chemotherapy, nanoparticle, nanometal, platinum, gold, silver.

\section{Introduction}

Cancer therapy is a multidisciplinary effort that requires involvement of different specialties, each providing specific services to the patient with the aim of ensuring that the patient receives optimum care and support. However, any innovation cannot be used directly in clinical practice, since any novel idea may intervene in the accepted procedure of therapy. Such challenges are now going to be solved thanks to evidence-based medicine (EBM) $[1 ; 2]$. Use of innovative materials, such as up-conversion nanoparticles, nanogold, quantum dots, magnetic nanoparticles and nanodiamonds has created a new and effective approach to fight cancer. Use of nanoparticles led to many opportunities in cancer diagnosis and treatment. Hybrid proteins and nanostructures can be used to affect in different ways affecting the tumor, for instance, by creating magnetic field, temperature, light, etc. To date, substantial accomplishments have been achieved, but in spite of all successes, many problems like biocompatibility, selective drug trans- fer, pharmacokinetics, safety and success of the chosen treatment remain unresolved [3].

In this regard, we performed this review to discuss novel achievements of metal nanoparticles in cancer therapy and challenges facing them.

\section{Multi-subject cancer therapy}

Cancers are usually represented by hematologic malignancies and malignant solid tumors [4]. Solid tumors are mainly carcinoma (epithelial origin) and sarcoma (mesenchymal origin), transition from epithelial origin to mesenchymal origin may occur as well $[5 ; 6]$.

The general protocol of cancer therapy includes different levels of chemotherapy, radiotherapy, medical and palliative therapy, and surgery. In hematologic malignancies, the first level is induction [7]. The chemotherapy at this level results in reduction of malignant cell numbers from $10^{11}$ to $10^{9}$ (approximately $99 \%$ ) within one month. The clinical manifestation of this reduction is named complete remis- 
sion [8]. Patients are then prepared for consolidation therapy (a 1 to 2-month period). Thereafter, the remaining malignant cells should be destroyed during a 1 to 2-year period of maintenance therapy [9]. In solid tumors, surgical resection is essential. Steps preceding and following it may be or not to be performed according to the type of cancer, its stage and clinical judgement of practitioners. Neoadjuvant chemotherapy preceeds the surgical resection. It results in clearance of tumor margins and helps surgeons to differentiate tumor margins during resection. Although level wise neoadjuvant chemotherapy of solid tumors is equivalent to induction level in treatment of hematologic malignancies, reduction of malignant cell numbers from $10^{11}$ to $10^{9}$ in solid tumors occurs after surgical level [10]. Level after surgical resection is called adjuvant chemoradiotherapy. The resection procedure can be $\mathrm{R} 0$ (without microscopic residue), R1 (without macroscopic residue) or R2 (with macroscopic residue). $\mathrm{R} 2$ is also called as palliative resection. Palliative therapy is used for the patients who are at end stages, have older ages or poor prognosis. Such patients are referred to palliative medicine ward [11]. We have indicated a comparison of cancer therapy levels in hematologic and solid malignancies through the lens of number of malignant cells in Figure 1 and Table 1.

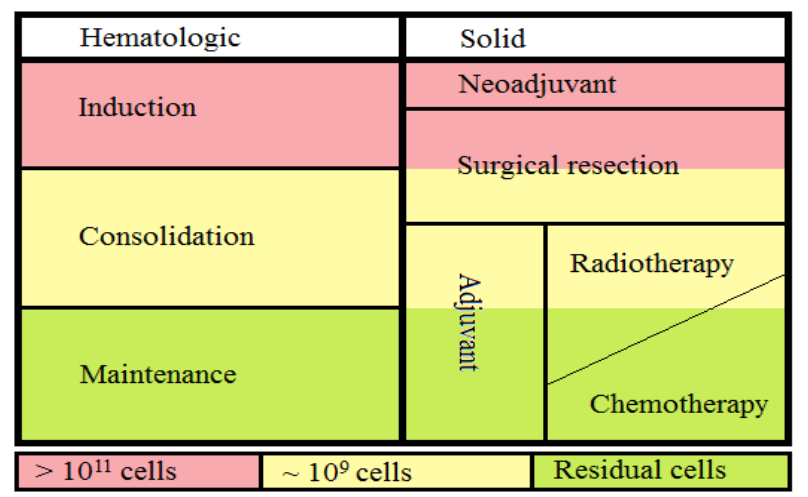

Figure 1 - Comparison of cancer therapy levels in hematologic and solid malignancies assessed by the number of malignant cells

Figure 1 shows that different levels are required to reduce the number of cancer cells in patient. All the levels should be completed to reduce the probability of recurrence. Nanodrugs can be used at these levels. For solid tumors, surgical resection is always necessary, except metastatic cancers.

Table 1 - Levels and principles of cancer therapy in general

\begin{tabular}{|c|c|c|c|c|c|}
\hline \multicolumn{7}{|c|}{ Type of malignancy (cancer) } \\
\hline Lematologic & Outcome & Level of therapy & Method & Outcome \\
\hline Induction & Chemotherapy & Complete remission & Neoadjuvant & Chemotherapy & Visibility of margins \\
\hline Consolidation & $\begin{array}{c}\text { Chemotherapy/ } \\
\text { BMT }\end{array}$ & $\begin{array}{c}\text { Clearance of } \\
\text { malignant cells }\end{array}$ & Resection & Surgery & $\begin{array}{c}\text { Clearance of } \\
\text { malignant cells }\end{array}$ \\
\hline Maintenance & $\begin{array}{c}\text { Chemotherapy/ } \\
\text { Radiotherapy }\end{array}$ & $\begin{array}{c}\text { Prevention of } \\
\text { relapse }\end{array}$ & Adjuvant & $\begin{array}{c}\text { Radiotherapy/ } \\
\text { Chemotherapy }\end{array}$ & $\begin{array}{c}\text { Prevention of } \\
\text { relapse }\end{array}$ \\
\hline $\begin{array}{c}\text { Palliative (if failure } \\
\text { to cure) }\end{array}$ & $\begin{array}{c}\text { Clinical and medical } \\
\text { care }\end{array}$ & $\begin{array}{c}\text { Increased quality } \\
\text { of life }\end{array}$ & $\begin{array}{c}\text { Palliative (if failure } \\
\text { to cure) }\end{array}$ & $\begin{array}{c}\text { Clinical and medical } \\
\text { care }\end{array}$ & $\begin{array}{c}\text { Increased quality } \\
\text { of life }\end{array}$ \\
\hline
\end{tabular}

Note: BMT: bone marrow transplantation

Table 1 shows the levels of cancer therapy in detail. Complete remission belongs the signs and symptoms which patients have them at the time of diagnosis. In solid tumors, neoadjuvant chemotherapy helps to increase visibility of the tumor margins for better surgical resection; in addition, a partial remission may be observed.

\section{Molecular bases of cancer and mTOR signal- ing pathway}

In general, if cell replication signals uncontrollably overcome cell cycle suppression signals a neoplastic tissue will be formed. Genes activating cell cycle are called proto-oncogenes and genes inhibit- 
ing cell cycle are called tumor-suppressor genes. The examples of proto-oncogenes are human epidermal growth factor receptor 2 (Her2), KRAS, beta-catenin, cyclin D1, c-Kit, vascular endothelial growth factor $(V E G F)$ and other. Monoclonal antibodies are used to target the products of these genes. For instance, trastuzumab targets Her2, imatinib targets c-Kit and bevacizumab targets VEGF [12].

Mammalian target of rapamycin (mTOR) is a center for multiple cell growth pathways and can be connected with multiple other proteins, which play important roles in cell growth. This system consists of two complexes; one of them is mTOR complex 1 and the other one is mTOR complex 2, which manage cellular processes by phosphorylation of major translation regulators, such as ribosomal S6 kinase and eukaryote initiation factor $4 \mathrm{E}$ binding protein. mTOR is sensitive to physiological responses dependent on cellular levels of oxygen, nutrients and energy. Due to its important roles in various cellular processes and diseases, mTOR is considered the molecular aim. mTOR is involved in obesity, depression and cancer and the importance of these diseases lead to production of the rapamycin, which in turn can inhibit mTOR and its analogs. mTOR signaling can be disrupted by genetic mutations, such as mutation in phosphatase and tensin homolog (PTEN) gene and cause several cancers like prostate, melanoma, breast, lung, endometrial, brain, thyroid, bladder and renal cancers. mTOR activity in both normal and cancer cells has been inhibited using different types of nanoparticles and results in reduction in the level of phosphorylated mTOR and subsequently mTORC1 catalytic activity [13-16].

\section{Use of metals and metal nanoparticles in diag- nosis and treatment of cancer}

Nanometals (metal nanoparticles) can be used both in diagnosis and treatment of cancer, including targeted drug delivery [17], tracking of malignant cells [18], magnetic-based hyperthermia treatment [18], etc. The latter results in expression of heat shock proteins by tumor cells and induction of apoptosis [19]. We summarized specific nanoparticles used for the specific cancer cell lines in Table 2 [20-37].

Table 2 - Effects of specific metal nanoparticles on specific cancer cell lines

\begin{tabular}{|c|c|c|c|}
\hline $\begin{array}{l}\text { Nanoparticle } \\
\text { (type) }\end{array}$ & Cancer (cell line) & Summary of findings & Ref. \\
\hline $\begin{array}{c}\text { Gold } \\
\text { (PEGylated) }\end{array}$ & $\begin{array}{l}\text { Reticulo-endothelial } \\
\text { system }\end{array}$ & $\begin{array}{l}\text { The aim of this study was to produce gold nanoparticles using plant- } \\
\text { mediated phytochemical extracts and take the conjugate particularly to } \\
\text { the tumor. It was proved that PEGylated gold nanoparticles can be used } \\
\text { as delivery vehicle for targeting small biomolecules (antibody etc.) to the } \\
\text { tumor location. }\end{array}$ & [23] \\
\hline $\begin{array}{l}\text { Gold (Au@QCS- } \\
\text { GA-FA) }\end{array}$ & $\begin{array}{l}\text { Lung cancer cells } \\
\text { (CHAGO) }\end{array}$ & $\begin{array}{l}\text { Quaternized chitosan-gallic acid-folic acid stabilized gold nanoparticles } \\
(\mathrm{Au} @ \mathrm{QCS}-\mathrm{GA}-\mathrm{FA}) \text { has enough potential to use as an anti-cancer agent. }\end{array}$ & [29] \\
\hline $\begin{array}{c}\text { Gold } \\
(\mathrm{Dox} \text { FA-GO@Au) }\end{array}$ & $\begin{array}{l}\text { Ehrlich Ascites Tumor } \\
\text { cells); EAT cells(-breast } \\
\text { cancer); MCF-7 cell line }\end{array}$ & $\begin{array}{l}\text { This study showed that gold nanoparticles can play important role in } \\
\text { tumor management. }\end{array}$ & [21] \\
\hline $\begin{array}{l}\text { Gold } \\
\text { (lycopene-nanogold } \\
\text { nanoemulsion) }\end{array}$ & $\begin{array}{l}\text { colon cancer cell line } \\
\quad(\text { HT-29) }\end{array}$ & $\begin{array}{l}\text { The aim of this study was to produce a nanoemulsion by the use of gold } \\
\text { nanoparticles and lycopene and study the effect of this nanoemulsion on } \\
\text { HT- } 29 \text { colon cancer cell line. } \\
\text { According to this study LP-nanogold nanoemulsion have sufficient effect } \\
\text { the treatment of colon cancer. }\end{array}$ & [27] \\
\hline $\begin{array}{l}\text { Gold } \\
\text { (Hyaluronic acid- } \\
\text { fabricated nanogold) }\end{array}$ & $\begin{array}{l}\text { Lung cancer cell line } \\
\qquad \text { (A549) }\end{array}$ & $\begin{array}{l}\text { Inhibitor of apoptosis protein-2 (IAP-2) was drived into A549 cells by the } \\
\text { use of gold nanoparticle and hyaluronic acid (AuNP-HA) and results to a } \\
\text { reduction in the cell proliferation. }\end{array}$ & [31] \\
\hline $\begin{array}{c}\text { Silver (Biogenic } \\
\text { silver nanoparticles) }\end{array}$ & $\begin{array}{l}\text { Human breast cancer } \\
\text { (MCF-7 cell lines) }\end{array}$ & $\begin{array}{l}\text { Biogenic silver nanoparticles showed their impressive role in inhibiting of } \\
\text { MCF-7 cell lines. }\end{array}$ & [30] \\
\hline $\begin{array}{l}\text { Silver (Plant derived } \\
\text { silver-nanoparticle) }\end{array}$ & $\begin{array}{l}\text { Colorectal cancer cell } \\
\text { line (HCT116) }\end{array}$ & PD-AgNP leads to apoptosis in colon cancer cells. & [34] \\
\hline $\begin{array}{c}\text { Nanoparticle } \\
\text { paclitaxel (NP PTX) }\end{array}$ & Lung Cancer & $\begin{array}{l}\text { Nanoparticle paclitaxel (NP PTX) caused G2/M phase cell cycle pause } \\
\text { and changed the microtubule dynamics resulting in cell death. }\end{array}$ & [25] \\
\hline
\end{tabular}


Continuation of Table 2

\begin{tabular}{|c|c|c|c|}
\hline $\begin{array}{l}\text { Nanoparticle } \\
\text { (type) }\end{array}$ & Cancer (cell line) & Summary of findings & Ref. \\
\hline Silver & $\begin{array}{l}\text { Human breast cancer } \\
\text { cells (MCF-7) }\end{array}$ & $\begin{array}{l}\text { AgNPs signified sufficient cytotoxicity impact against MCF-7 at minimal } \\
\text { dosage. }\end{array}$ & [35] \\
\hline $\begin{array}{c}\text { Nanodiamond/ } \\
\text { nanoplatinum }\end{array}$ & Breast cancer cells $(4 \mathrm{~T} 1)$ & $\begin{array}{l}\text { nanodiamond/nanoplatinum can be used as cancer therapy agent owing to } \\
\text { its ability to reduce cell stiffness. }\end{array}$ & [24] \\
\hline Silver & $\begin{array}{l}\text { Prostate cancer cells } \\
\text { (PC3) }\end{array}$ & Prostate cancer cells can be destroyed by cytotoxic effects of Nanosilver. & [22] \\
\hline $\begin{array}{l}\text { Silver } \\
\text { (TAT-modified } \\
\text { nanosilver) }\end{array}$ & $\begin{array}{l}\text { Multidrug-resistant } \\
\text { (MDR) cancer- } \\
\text { melanoma }\end{array}$ & $\begin{array}{l}\text { AgNP-TAT is a strong anticancer nanoparticle and can inhibit MDR, non- } \\
\text { resistance cells and the tumor growth. }\end{array}$ & [32] \\
\hline Silver & $\begin{array}{l}\text { Human oral squamous } \\
\text { cell carcinoma (HSC-3) }\end{array}$ & $\begin{array}{l}\text { The main purpose was the comparison of intracellular impacts between } \\
\text { silver nanoparticles (AgNPs) conjugated with nuclear and cytoplasmic } \\
\text { targeting peptides and peptide-conjugated gold nanoparticles (AuNPs). } \\
\text { Treated cell with AgNPs showed DNA damage and apoptosis. }\end{array}$ & [20] \\
\hline $\begin{array}{l}\text { Epigallocatechin- } \\
\text { 3-gallate-gold } \\
\text { nanoparticles } \\
\text { (EGCG-pNG) }\end{array}$ & Bladder cancer & $\begin{array}{l}\text { EGCG-pNG as a antitumor agent can inhibit tumor cell growing owing to } \\
\text { apoptosis. }\end{array}$ & [26] \\
\hline $\begin{array}{l}\text { Fluorophore- } \\
\text { nanoparticle }\end{array}$ & Breast cancer & $\begin{array}{l}\text { fluorophore-nanoparticle can be utilized as a designed complex to target } \\
\text { breast cancer by emitting fluorescence conditionally. }\end{array}$ & [36] \\
\hline Gold & Liver cancer & $\begin{array}{l}\text { Nanogold revealed its potential for inhibiting of the angiogenesis and } \\
\text { growth of liver cancer cells because of inhibition of the VEGF165- } \\
\text { induced signaling. }\end{array}$ & [33] \\
\hline Gold & Breast cancer & $\begin{array}{l}\text { The aim was to develop a tumor-specific multi-functional, nano-entity } \\
\text { which is able to detect and treat cancer. } \\
\text { gold-coated Fe } 3 \mathrm{O} 4 \text { nanoparticles are tumor-specific nano-agents and can } \\
\text { play important roles in detection and hyperthermia for breast cancer. }\end{array}$ & [28] \\
\hline Gold & $\begin{array}{l}\text { Colorectal carcinoma } \\
\text { cell line (HT29) }\end{array}$ & $\begin{array}{l}\text { The goal was to study that AuNPs can influence the epithelial origin cell } \\
\text { lines: continuous and oncogenic. Cell line of HT } 29 \text { showed sensitiveness } \\
\text { to the effects of AuNPs. }\end{array}$ & [37] \\
\hline
\end{tabular}

Based on results, platinum (Pt)-based drugs are some of the most effective drugs used for cancer chemotherapy. One of the efficient Pt-based anti-tumor drugs is Cisplatin (Cis-diamminedichloroplatinumII). It was approved in 1978 and is used for treatment of various cancers such as testicular, prostate, bladder and lung cancers. Therapeutic function of Pt-based drugs is binding to DNA and stopping its replication. Cisplatin cannot be used for all types of cancers and resistance to it has been observed. Ptbased complexes showed promising cytotoxic effect due to their structural properties $[38 ; 39]$. Other than conventional use of this metal, Pt-based nanoparticles have been studied. These particles have radiosensitizing properties in comparison to metal atoms of Pt [40].

Gold (Au) nanoparticles are commonly used in cancer treatment and diagnostics. For instance, combinations of gold nanoparticles with anti-tumor marker antibodies have been used as biosensors [41]. Due to their physiochemical properties, gold nanoparticles can be used for hyperthermia-based treatment of cancer [42]. Their possibility to act as radiosensitizers has also been shown [40].

Silver (Ag) is known as a metal with antimicrobial and anticancer effects. Previously, silver containing compounds have been shown to have antimicrobial and anticancer effects via induction of necrosis and late apoptosis [43]. According to these effects, nanoparticles of silver are also used [44]. Silver nanoparticles are usually synthesized by medicinal plants (green nanoparticles) [45].

Iron is another metal used in cancer therapy. It is suitable for heat induction. It has been previously proved that magnetic nanoparticles can destroy tumor cells by heat delivery and use of alternating electromagnetic field. Magnetic materials, such as iron oxide $\left(\mathrm{Fe}_{2} \mathrm{O}_{3}\right.$ or $\left.\mathrm{Fe}_{3} \mathrm{O}_{4}\right)$ are the most used materials 
for hyperthermia. Nanoparticles can be employed as tumor hyperthermic treatment because of their ability to be utilized as a heat guide, where their sufficiency depends on their size. The best size of the particles to get heated well is within the range of 10-30 nm. Noninvasive hyperthermic therapy may be feasible by heating a tumor model containing nanoparticles. $\mathrm{Ab}-$ sorption of near-infrared reflectance can be improved using gold nanoparticles. Utilization of coated $\mathrm{Fe}_{3} \mathrm{O}_{4}$ nanoparticles with gold is a useful method for optical/ thermal markers for seamless diagnosis and therapy in a minimally invasive way. This approach has been used towards the breast cancer cell lines [46; 47].

Medical plants and antioxidants can be used for their anticancer effects as well as their pain relieving effects [48]. For pathophysiology of cancers, role of mutilation in apoptotic related genes [49] and angiogenic factors was investigated [50]. We also found that immune cells, such as natural killers might be involved in cancer [51].

\section{Conclusion}

This review was aimed to investigate the use of nanometals gold-based, silver-based, platinum-based and iron-based in cancer treatment. According to literature, specific metal nanoparticles can inhibit cell lines of different cancers based on in vitro experimental studies. In vivo studies were focused on magnetic, heat induction and ability to track effects. Metals (as single atom or in combination with other compounds) had been previously used in different diseases. Cancer had been a major concern and hence metals were studied for cancer treatment. Nanotechnology was added to this idea and therefore metal nanoparticles were innovated. They are used according to their targeted effect, magnetic potencies and heat induction as well as tracking cancer cells for diagnostic aims. Use of nanoparticles should not intervene with the accepted levels of cancer therapy. Therefore, such agents should be used as a combination therapy and levels of evidence should be regarded and updated.

\section{Acknowledgement}

We would like to express our gratitude to Dr. M. Rafieian Kopaei for his valuable help in pharmacology.

\section{References}

1. Kaasa S., De Conno F. (2001) Palliative care research. Europ J Cancer, vol. 37, no 8, pp. 153-159.

Int. j. biol. chem. (Online)
2. Brescia F.J. (2001) Lung cancer - a philosophical, ethical, and personal perspective. Crit Rev Oncol Hematol., vol. 40, no. 2, pp. 139-148.

3. Deyev S., Lebedenko E. (2017) Targeted bifunctional proteins and hybrid nanoconstructs for cancer diagnostics and therapies. Mol Biol., vol. 51, no. 6 , pp. $788-803$.

4. Jordan C.T. (2004). Cancer stem cell biology: from leukemia to solid tumors. Curr Opin Cell Biol., vol. 16, no. 6, pp. 708-712.

5. Christiansen J.J., Rajasekaran A.K. (2006). Reassessing epithelial to mesenchymal transition as a prerequisite for carcinoma invasion and metastasis. Cancer Res., vol. 66, no. 17, pp. 8319-8326.

6. Thiery J.P. (2002) Epithelial-mesenchymal transitions in tumour progression. Nat Rev Cancer, vol. 2 , no. 6 , p. 442 .

7. Johnson S.B., Park H.S., Gross C.P., James B.Y. (2018). Complementary medicine, refusal of conventional cancer therapy, and survival among patients with curable cancers. JAMA oncology, vol. 4, no. 10 , pp. $1375-1381$.

8. Ronghe M.D., Murphy D. (2016). Chemotherapy and novel cancer targeted therapies, Surgery Childhood Tum., pp. 135-152.

9. Jacene H.A., Tirumani S.H., Wahl R.L. (2017). Radionuclide Therapy of Lymphomas. In: Strauss H., Mariani G., Volterrani D., Larson S. (eds.) Nuclear Oncology. Springer.

10. Funt S.A., Chapman P.B. (2016). The role of neoadjuvant trials in drug development for solid tumors. Clin Cancer Res., vol. 22, no. 10, pp. 23232328.

11. Hong T.S., Ryan D.P. (2015). Adjuvant chemotherapy for locally advanced rectal cancer: is it a given. J Clin Oncol., vol. 33, no. 17, pp. 1878-1880.

12. Chial H. (2008). Proto-oncogenes to oncogenes to cancer. Nat Educ., vol. 1, no. 1, pp. 33.

13. Serej F.A., Pourhassan-Moghaddam M., Kalan M.E., Mehdipour A., Serej Z.A., Ebrahimi-Kalan A. (2018). Targeting the PI3K/Akt/mTOR signaling pathway: applications of nanotechnology. Crescent $J$ Med Biol Sci., vol. 5, no. 1, pp. 7-13.

14. Xu Y., Islam M.A., Zope H., Mahmoudi M., Langer R.S., Shi J., et al. (2017). Restoration of tumor suppression in vivo by systemic delivery of PTEN mRNA nanoparticles. J Clin Oncol., vol. 35, no. 15, pp. 11582-11582.

15. De Araújo Jr R.F., Pessoa J.B., Cruz L.J., Chan A.B., De Castro Miguel E., Cavalcante R.S., et al. (2018). Apoptosis in human liver carcinoma caused by gold nanoparticles in combination with carvedilol is mediated via modulation of MAPK/ 
Akt/mTOR pathway and EGFR/FAAD proteins. Int J Oncol., vol. 52, no. 1, pp. 189-200.

16. Wang W.-J., Yang W., Ouyang Z.-H., Xue J.-B., Li X.-L., Zhang J., et al. (2018). MiR-21 promotes ECM degradation through inhibiting autophagy via the PTEN/akt/mTOR signaling pathway in human degenerated NP cells. Biomed Pharmacother., vol. 99, pp. 725-734.

17. Medina-Ramirez I., Gonzalez-Garcia M., Palakurthi S., Liu J. (2012). Application of nanometals fabricated using green synthesis in cancer diagnosis and therapy. Green Chemistry-Environmentally Benign Approaches. IntechOpen, ISBN 978-953-510334-9.

18. Kumar C.S.S.R., Mohammad F. (2011). Magnetic nanomaterials for hyperthermia-based therapy and controlled drug delivery. Adv Drug Deliv Rev., vol. 63, no. 9, pp. 789-808.

19. Kobayashi T., Kakimi K., Nakayama E., Jimbow K. (2014). Antitumor immunity by magnetic nanoparticle-mediated hyperthermia. Nanomed., vol. 9, no. 11, pp. 1715-1726.

20. Austin L.A., Kang B., Yen C.-W., El-Sayed M.A. (2011). Nuclear targeted silver nanospheres perturb the cancer cell cycle differently than those of nanogold. Bioconjug Chem., vol. 22, no. 11, pp. 2324-2331.

21. Chauhan G., Chopra V., Tyagi A., Rath G., Sharma R.K., Goyal A.K. (2017). Gold nanoparticles composite-folic acid conjugated graphene oxide nanohybrids for targeted chemo-thermal cancer ablation: in vitro screening and in vivo studies. Europ $J$ Pharm Sci., vol. 96, pp. 351-361.

22. Firdhouse M.J., Lalitha P. (2013). Biosynthesis of silver nanoparticles using the extract of Alternanthera sessilis - antiproliferative effect against prostate cancer cells. Cancer Nanotechnol., vol. 4, no. 6 , pp. $137-143$.

23. Garg P., Hazra D.K. (2017). Conjugation of antibodies with radiogold nanoparticles, as an effector targeting agents in radiobioconjugate cancer therapy: Optimized labeling and biodistribution results. Indian J Nuclear Med., vol. 32, no. 4, pp. 296.

24. Ghoneum A., Zhu H., Woo J., Zabinyakov N., Sharma S., Gimzewski J.K. (2014). Biophysical and morphological effects of nanodiamond/nanoplatinum solution (DPV576) on metastatic murine breast cancer cells in vitro. Nanotech., vol. 25, no. 46, pp. 465101.

25. Hariri G., Edwards A.D., Merrill T.B., Greenbaum J.M., van der Ende A.E., Harth E. (2013). Sequential targeted delivery of paclitaxel and camp-

Int. j. biol. chem. (Online) tothecin using a cross-linked "nanosponge" network for lung cancer chemotherapy. Mol Pharm., vol. 11, no. 1 , pp. 265-275.

26. Hsieh D.-S., Wang H., Tan S.-W., Huang Y.H., Tsai C.-Y., Yeh M.-K., et al. (2011). The treatment of bladder cancer in a mouse model by epigallocatechin-3-gallate-gold nanoparticles. Biomat., vol. 32, no. 30, pp. 7633-7640.

27. Huang R.-F.S., Wei Y.-J., Inbaraj B.S., Chen B.-H. (2015). Inhibition of colon cancer cell growth by nanoemulsion carrying gold nanoparticles and lycopene. Int J Nanomed., vol. 10, pp. 2823.

28. Jin H., Hong B., Kakar S.S., Kang K.A. (2008). Tumor-specific nano-entities for optical detection and hyperthermic treatment of breast cancer. Oxygen Transport to Tissue XXIX. Springer, pp. 275-284.

29. Komenek S., Luesakul U., Ekgasit S., Vilaivan T., Praphairaksit N., Puthong S., et al. (2017). Nanogold-gallate chitosan-targeted pulmonary delivery for treatment of lung cancer. AAPS Pharm Sci Tech., vol. 18, no. 4, pp. 1104-1115.

30. Lalitha P. (2015). Apoptotic efficacy of biogenic silver nanoparticles on human breast cancer MCF-7 cell lines. Prog Biomater., vol. 4, no. 2-4, pp. 113-121.

31. Lin C.-M., Kao W.-C., Yeh C.-A., Chen H.J., Lin S.-Z., Hsieh H.-H., et al. (2015). Hyaluronic acid-fabricated nanogold delivery of the inhibitor of apoptosis protein-2 siRNAs inhibits benzo [a] pyrene-induced oncogenic properties of lung cancer A549 cells. Nanotech., vol. 26, no. 10, pp. 105101.

32. Liu J., Zhao Y., Guo Q., Wang Z., Wang H., Yang Y., et al. (2012). TAT-modified nanosilver for combating multidrug-resistant cancer. Biomat., vol. 33, no. 26, pp. 6155-6161.

33. Pan Y.L., Qiu S.Y., Qin L., Cai J.Y., Sun J.S. (2009). Nanogold inhibits angiogenesis and growth of liver cancer: experiment with mice. Zhonghua yi xue za zhi., vol. 89, no. 12, pp. 800-804.

34. Satapathy S.R., Mohapatra P., Das D., Siddharth S., Kundu C.N. (2015). The apoptotic effect of plant based nanosilver in colon cancer cells is a p53 dependent process involving ROS and JNK cascade. Pathol Oncol Res., vol. 21, no. 2, pp. 405-411.

35. Sathishkumar G., Gobinath C., Wilson A., Sivaramakrishnan S. (2014). Dendrophthoe falcata (Lf) Ettingsh (Neem mistletoe): a potent bioresource to fabricate silver nanoparticles for anticancer effect against human breast cancer cells (MCF-7). Spectrochim Acta Part A, vol. 128, pp. 285-290.

36. Wang J., Nantz M.H., Achilefu S., Kang K.A. (2010). FRET-like fluorophore-nanoparticle 
complex for highly specific cancer localization. Oxygen transport to Tissue XXXI. Springer, pp. 407-413.

37. Pavlovich E., Volkova N., Yakymchuk E., Perepelitsyna O., Sydorenko M., Goltsev A. (2017). In vitro study of influence of $\mathrm{Au}$ nanoparticles on HT29 and SPEV cell lines. Nanoscale Res Lett., vol. 12, no. 1, pp. 494.

38. Kelland L. (2007). The resurgence of platinum-based cancer chemotherapy. Nat. Rev. Cancer, vol. 7, no. 8, pp. 573.

39. Shahsavar F., Bozorgmehr M., Mirzadegan E., Abedi A., Mehri Lighvan Z., Mohammadi F., et al. (2016). A novel platinum-based compound with preferential cytotoxic activity against a panel of cancer cell lines. Anti-Cancer Agents Med Chem., vol. 16, no. 3, pp. 393-403.

40. Porcel E., Liehn S., Remita H., Usami N., Kobayashi K., Furusawa Y., et al. (2010). Platinum nanoparticles: a promising material for future cancer therapy? Nanotech., vol. 21, no. 8, pp. 085103.

41. Nekouian R., Khalife N.J., Salehi Z. (2014). Anti human fibronectin-gold nanoparticle complex, a potential nanobiosensor tool for detection of fibronectin in ECM of cultured cells. Plasmonics. vol. 9, no. 6 , pp. 1417-1423.

42. Bhattacharyya S., Kudgus R.A., Bhattacharya R., Mukherjee P. (2011). Inorganic nanoparticles in cancer therapy. Pharm res., vol. 28, no. 2, pp. 237259.

43. Rendosova M., Vargova Z., Sabolova D., Imrichova N., Hudecova D., Gyepes R., et al. (2018). Silver pyridine-2-sulfonate complex - its characterization, DNA binding, topoisomerase I inhibition, antimicrobial and anticancer response. J Inorg Biochem., vol. 186, no., pp. 206-216.

44. Ahmad S., Munir S., Zeb N., Ullah A., Khan B., Ali J., Salman S.M., Ali S. (2019). Green nanotechnology: a review on green synthesis of silver nanoparticles - an ecofriendly approach. Int J Nanomed., vol. 14, pp. 5078-5107.

45. Kathiravan V., Ravi S., Ashokkumar S. (2014). Synthesis of silver nanoparticles from Melia dubia leaf extract and their in vitro anticancer activity. Spectrochim Acta Part A: Mol Biomol Spectr., vol. 130, pp. 116-121.

46. Bickford L.R., Agollah G., Drezek R., Yu T.-K. (2010). Silica-gold nanoshells as potential intraoperative molecular probes for HER2-overexpression in ex vivo breast tissue using near-infrared reflectance confocal microscopy. Breast Cancer Res Treat., vol. 120, no. 3, pp. 547-555.

47. Lee J., Chatterjee D.K., Lee M.H., Krishnan S. (2014). Gold nanoparticles in breast cancer treatment: promise and potential pitfalls. Cancer Lett., vol. 347 , no. 1 , pp. $46-53$.

48. Kheirollahi A., Hasanvand A., Abbaszadeh S., Momeni Safarabadi A., Moghadasi M. (2019). Pathophysiology and urinary system cancer: an overview of the most important herbal plants and natural antioxidants on kidney and bladder disorders. Res $J$ Pharm Tech., vol. 12, no. 2, pp. 972-980.

49. Nikbakht M., Jha A.K., Malekzadeh K., Askari M., Mohammadi S., Marwaha R. K., Kaul D., Kaur, J. (2017). Aberrant promoter hypermethylation of selected apoptotic genes in childhood acute lymphoblastic leukemia among North Indian population. Exp Oncol., vol. 39, no. 1, pp. 57-64.

50. Haghi,A., Mohammadi S., Heshmati M., Ghavamzadeh A., Nikbakht M. (2017). Anti-vascular endothelial growth factor effects of sorafenib and arsenic trioxide in acute myeloid leukemia cell lines. Asian Pac J Cancer Prev., vol. 18, no. 6, pp. 16551661.

51. Ghanadi K., Shayanrad B., Ahmadi S.A.Y., Shahsavar F., Eliasy, H. (2016). Colorectal cancer and the KIR genes in the human genome: a metaanalysis. Genom Data, vol. 10, no. c, pp. 118-126. 